\title{
5WBF: a low-cost and straightforward whole blood filtration method suitable for whole-genome sequencing of Plasmodium falciparum clinical isolates
}

\author{
Romain Coppée ${ }^{1,6^{*}}$, Atikatou Mama ${ }^{1 \dagger}$, Véronique Sarrasin ${ }^{1,2+}$, Claire Kamaliddin ${ }^{2,3}$, Lucie Adoux ${ }^{4}$, \\ Lawrence Palazzo ${ }^{1}$, Nicaise Tuikue Ndam ${ }^{1}$, Franck Letourneur ${ }^{4}$, Frédéric Ariey ${ }^{5}$, Sandrine Houzé ${ }^{1,2}$ and \\ Jérôme Clain ${ }^{1,2^{*}}$
}

\begin{abstract}
Background: Whole-genome sequencing (WGS) is becoming increasingly helpful to assist malaria control programmes. A major drawback of this approach is the large amount of human DNA compared to parasite DNA extracted from unprocessed whole blood. As red blood cells (RBCs) have a diameter of about 7-8 $\mu \mathrm{m}$ and exhibit some deformability, it was hypothesized that cheap and commercially available $5 \mu \mathrm{m}$ filters might retain leukocytes but much less of Plasmodium falciparum-infected RBCs. This study aimed to test the hypothesis that such a filtration method, named 5WBF (for $\underline{5} \mu \mathrm{m}$ Whole $\underline{B}$ lood Filtration), may provide highly enriched parasite material suitable for $P$. falciparum WGS.

Methods: Whole blood was collected from five patients experiencing a P. falciparum malaria episode (ring-stage parasitaemia range: $0.04-5.5 \%$ ) and from mock samples obtained by mixing synchronized, ring-stage cultured $P$. falciparum 3D7 parasites with uninfected human whole blood (final parasitaemia range: $0.02-1.1 \%$ ). These whole blood samples (50 to $400 \mu \mathrm{L}$ ) were diluted in RPMI 1640 medium or PBS $1 \times$ buffer and filtered with a syringe connected to a $5 \mu \mathrm{m}$ commercial filter. DNA was extracted from $5 \mathrm{WBF}$-treated and unfiltered counterpart blood samples using a commercial kit. The $5 \mathrm{WBF}$ method was evaluated on the ratios of parasite:human DNA assessed by qPCR and by sequencing depth and percentages of coverage from WGS data (Illumina NextSeq 500). As a comparison, the popular selective whole-genome amplification (sWGA) method, which does not rely on blood filtration, was applied to the unfiltered counterpart blood samples.

Results: After applying 5WBF, qPCR indicated an average of twofold loss in the amount of parasite template DNA (Pf ARN18S gene) and from 4096- to 65,536-fold loss of human template DNA (human $\beta$ actin gene). WGS analyses revealed that $>95 \%$ of the parasite nuclear and organellar genomes were all covered at $\geq 10 \times$ depth for all samples tested. In sWGA counterparts, the organellar genomes were poorly covered and from 47.7 to $82.1 \%$ of the nuclear genome was covered at $\geq 10 \times$ depth depending on parasitaemia. Sequence reads were homogeneously distributed across gene sequences for 5 WBF-treated samples ( $n=5460$ genes; mean coverage: $91 x$; median coverage: $93 \times$; 5 th
\end{abstract}

\footnotetext{
${ }^{*}$ Correspondence: romain.coppee@gmail.com; jerome.clain@u-paris.fr

${ }^{\dagger}$ Atikatou Mama and Véronique Sarrasin contributed equally to this work

${ }^{1}$ Université de Paris, IRD, MERIT, 75006 Paris, France

Full list of author information is available at the end of the article
}

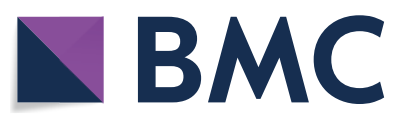

(c) The Author(s) 2022. Open Access This article is licensed under a Creative Commons Attribution 4.0 International License, which permits use, sharing, adaptation, distribution and reproduction in any medium or format, as long as you give appropriate credit to the original author(s) and the source, provide a link to the Creative Commons licence, and indicate if changes were made. The images or other third party material in this article are included in the article's Creative Commons licence, unless indicated otherwise in a credit line to the material. If material is not included in the article's Creative Commons licence and your intended use is not permitted by statutory regulation or exceeds the permitted use, you will need to obtain permission directly from the copyright holder. To view a copy of this licence, visit http://creativecommons.org/licenses/by/4.0/. The Creative Commons Public Domain Dedication waiver (http://creativeco mmons.org/publicdomain/zero/1.0/) applies to the data made available in this article, unless otherwise stated in a credit line to the data. 
percentile: 70x; 95th percentile: 103x), allowing the identification of gene copy number variations such as for gch1. This later analysis was not possible for sWGA-treated samples, as a much more heterogeneous distribution of reads across gene sequences was observed (mean coverage: $80 x$; median coverage: $51 x$; 5 th percentile: $7 x$; 95 th percentile: $245 x$ ).

Conclusions: The novel 5WBF leucodepletion method is simple to implement and based on commercially available, standardized $5 \mu \mathrm{m}$ filters which cost from 1.0 to $1.7 €$ per unit depending on suppliers. 5WBF permits extensive genome-wide analysis of $P$. falciparum ring-stage isolates from minute amounts of whole blood even with parasitaemias as low as $0.02 \%$.

Keywords: Malaria, Plasmodium falciparum, Leucodepletion, Filtration, Whole-genome sequencing

\section{Background}

Whole-genome sequencing (WGS) has revolutionized genome-wide analyses [1]. In the context of Plasmodium falciparum surveillance, WGS is helpful for example to analyse the structure of parasite populations [2,3] and to identify and track gene mutations conferring resistance to anti-malarial drugs $[4,5]$. A major drawback of WGS is the large amount of human DNA compared to parasite DNA when extracted from unprocessed whole blood. Several protocols have been developed to enrich parasite DNA before WGS, either by filtering out leukocytes before DNA extraction or by selectively amplifying the parasite genome (sWGA). Current filtration procedures based on leucodepletion are however limited because they require large volumes of venous blood [6] or use either home-made cellulose-packed columns [7] or costly commercial filters [8]. Regarding sWGA-based methods [9-11], studies reported a large proportion of unmapped reads to the $P$. falciparum genome [12], the absence of coverage of the organellar genomes [9], and a wide heterogeneity in read distribution across the nuclear genome [9]. Altogether, there is a need to improve clinical sample preparation to increase data quality and exhaustiveness for P. falciparum genomic studies while limiting the cost of data production.

Mature red blood cells (RBCs) have a resting long diameter of about $\sim 8 \mu \mathrm{m}$ and exhibit some deformability [13]. Using a microfluidic device to examine the traversal of a RBC, the diameters of the smallest equivalent cylindrical tube, through which uninfected and parasitized RBCs could pass, were similar $(2.78$ and $2.79 \mu \mathrm{m}$, respectively) [13]. Human leukocytes are larger cells than RBCs and have diameters ranging from 9 to $21 \mu \mathrm{m}$ depending on cell types. Hence, it was hypothesized that commercially available filters with a pore size of $5 \mu \mathrm{m}$ might retain DNA-carrying human leukocytes but not $P$. falciparuminfected RBCs. Such a filtration could provide samples highly enriched in parasites, suitable for downstream WGS workflow. On this basis, the 5WBF method (5 $\mu \mathrm{m}$ Whole Blood Filtration), a low-cost and simple blood filtration procedure using a commercial, standardized
$5 \mu \mathrm{m}$ filter (Minisart NML ${ }^{\circledR}$ syringe, Sartorius AG, Germany), was developed. To demonstrate the usefulness of $5 \mathrm{WBF}, 400 \mu \mathrm{L}$ of whole blood at variable parasitaemias (from 0.022 to $1.1 \%$ ) was first tested from mock samples made by mixing synchronized, ring-stage cultured $P$. falciparum parasitized erythrocytes (3D7) with uninfected human whole blood. Then $5 \mathrm{WBF}$ was validated using 50 and $200 \mu \mathrm{L}$ of whole blood from patients experiencing a $P$. falciparum malaria episode (ring-stage parasitaemia range: $0.04-5.5 \%)$. DNA extracts obtained after $5 \mathrm{WBF}$ were evaluated using the parasite:human DNA ratio assessed by qPCR and the performance of sequencing depth and percentages of coverage obtained through WGS data compared with sWGA.

\section{Methods}

\section{Plasmodium falciparum culture and infected whole blood reconstitution}

Mock whole blood samples were obtained by mixing a synchronized ring-stage $P$. falciparum culture (O-negative blood, 3D7 parasite strain) with uninfected human whole blood (final parasitaemia range: $0.022-1.1 \%$ ). 3D7 parasites were cultured at $37{ }^{\circ} \mathrm{C}$ under specific atmospheric conditions ( $10 \%$ oxygen, $5 \%$ carbon dioxide and $85 \%$ nitrogen) in $10 \%$ human serum containing RPMI 1640 medium. One volume of pelleted culture at $10 \%$ parasitaemia was diluted in ten volumes of non-infected human whole blood. The mock sample parasitaemia was estimated to be $1.1 \%$ by Diff Quick $^{\mathrm{TM}}$-stained thin blood film. The sample was then diluted 1:5 followed by another 1:10 dilution in the negative human whole blood as three independent replicates. The parasitaemias were estimated by Diff Quick ${ }^{\mathrm{TM}}$-stained, thin blood film to be $0.23 \%$ and $0.022 \%$ for the two diluted samples, respectively. These reconstituted, infected whole blood samples were hereafter called mock samples.

Infected whole blood from $P$. falciparum malaria patients Five fresh blood samples (collected on EDTA) from imported $P$. falciparum malaria cases diagnosed and treated at Bichat - Claude-Bernard Hospital (French 
Malaria Reference Centre, Paris, France) were arbitrarily selected. Diff Quick $^{\mathrm{TM}}$-stained blood film examination indicated monospecific $P$. falciparum infections with ring-stage parasitaemias ranging from 0.04 to $5.5 \%$. Additional clinical information is provided for each patient in Additional file 1: Table S1.

\section{WBF procedure}

Prior to filtration, whole blood was diluted in either PBS $1 \times$ buffer or RPMI 1640 medium (Fig. 1, Table 1 and Additional file 1: Fig. S1). For mock samples, 400 $\mu \mathrm{L}$ of whole blood were diluted in ten volumes of PBS $1 \times$ buffer. For patient samples, $50 \mu \mathrm{L}$ and $200 \mu \mathrm{L}$ of whole blood were diluted in 30 volumes of RPMI 1640 medium, as using small sample volumes would result in large sample loss (Table 1). Each diluted blood sample was then loaded into a $10 \mathrm{~mL}$ syringe and filtered using a $5 \mu \mathrm{m}$ surfactant-free cellulose acetate syringe filter (Minisart $\mathrm{NML}^{\circledR}$ syringe filter, Sartorius reference number: 17594K) connected to the syringe (Fig. 1). The sample was filtered by a very gentle push with the syringe plunger such that the filtrate flew drop by drop. Importantly, the plunger was pushed down to the bottom of the syringe. Note that even though the filtrate might pass through by gravity only, using the plunger is seemingly important to recover a maximum of infected RBCs. For mock samples only, the filter membrane was rinsed with another $2 \mathrm{~mL}$ of PBS $1 \times$ buffer (Table 1 ). As it was noticed that skipping the rinsing step produced satisfactory WGS results, this step was not included for the second part of the study on parasite isolates from patients in order to simplify the protocol. The filtrate was then centrifuged at $2500 \mathrm{~g}$ for $5 \mathrm{~min}$ at room temperature and the supernatant was discarded (Fig. 1). One pellet volume of RPMI 1640 (clinical samples) or PBS $1 \times$ (mock samples) was added to the pelleted RBCs which were transferred into $1.5 \mathrm{~mL}$ tube and stored at $4{ }^{\circ} \mathrm{C}$ until DNA extraction within the next $24 \mathrm{~h}$ (Table 1). The filtration step itself is very quick (1 to $3 \mathrm{~min}$ ), and the whole procedure takes about $20 \mathrm{~min}$. Note that, for practical reason, a slightly different protocol was also tested in which the diluted blood sample was loaded into a $10 \mathrm{~mL}$ syringe after the $5 \mu \mathrm{m}$ filter was connected to the syringe (Additional file 1: Fig. S1); similar results were obtained than with the protocol described in Fig. 1.

As a negative control for filtration, whole blood (400 $\mu \mathrm{L}$ ) for one mock sample (parasitaemia of $1.1 \%$ ) was subjected to the same pipeline similarly to other mock samples, except that no filter was connected at the bottom of the syringe (Table 1). This control mock sample was latter called M1.

\section{DNA extraction}

DNA extraction was carried out on unfiltered and 5WBF-treated samples using the MagPurix ${ }^{\circledR}$ Blood DNA Extraction Kit 200 (Biosynex, France), then eluted using the elution buffer according to the manufacturer's recommendations (Table 1). DNA was quantified using the

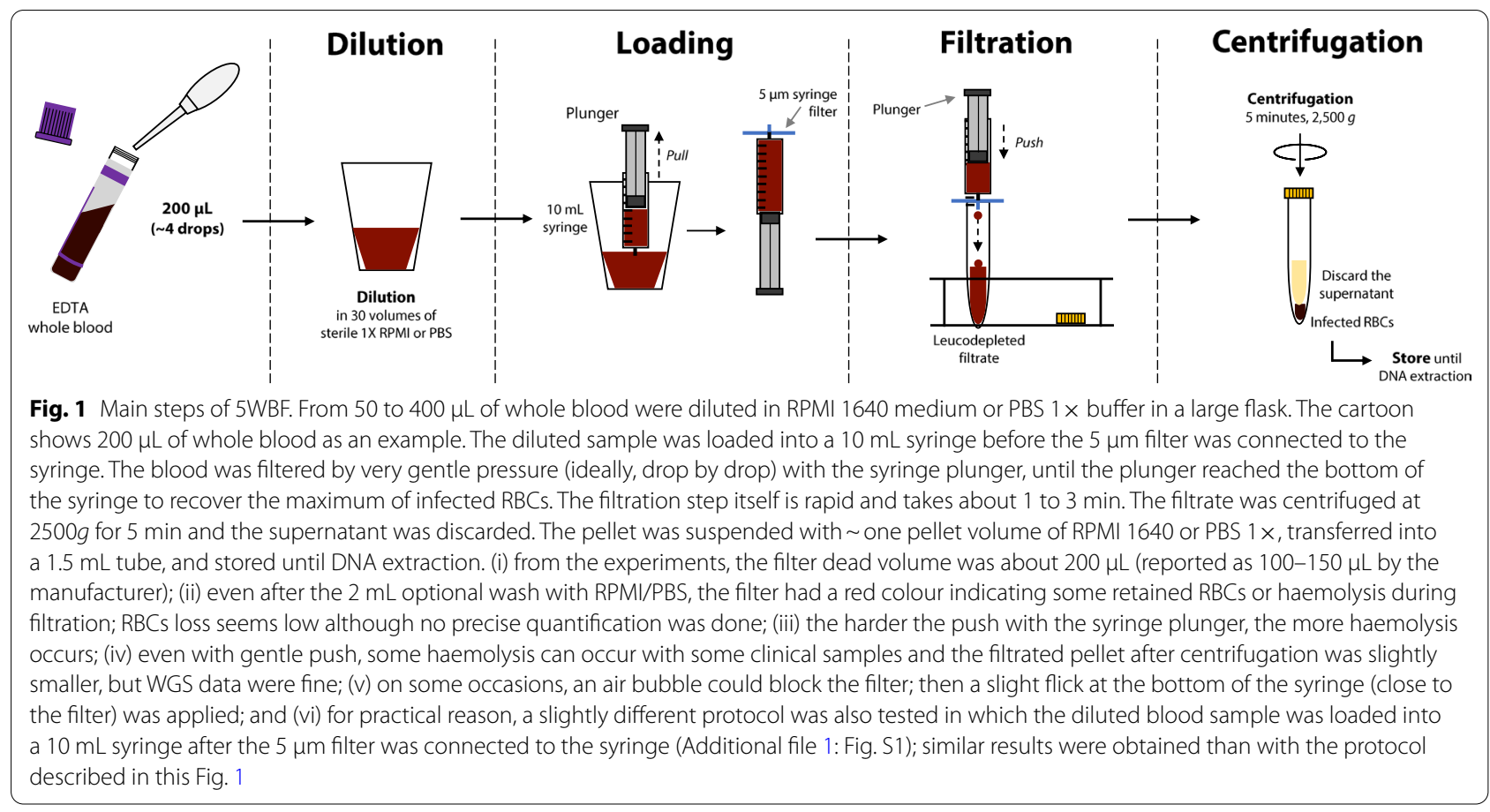


Table 1 Details of samples subjected to WGS

\begin{tabular}{|c|c|c|c|c|c|c|c|}
\hline Origin & Sample name & $\begin{array}{l}\text { Enrichment } \\
\text { method }\end{array}$ & $\%$ para & $\begin{array}{l}\text { Blood } \\
\text { volume }(\mu \mathrm{L})\end{array}$ & Blood:buffer dilution & $\begin{array}{l}\text { Washing filter } \\
\text { membrane }^{\mathrm{a}}\end{array}$ & $\begin{array}{l}\text { Volume of DNA } \\
\text { elution buffer } \\
(\mu \mathrm{L})^{\mathrm{b}}\end{array}$ \\
\hline \multirow[t]{13}{*}{ Mock (3D7) } & M1 & None & 1.10 & 400 & n.a & n.a & 200 \\
\hline & $M 1_{\text {WGA }}$ & sWGA & 1.10 & 400 & n.a & n.a & 200 \\
\hline & $M 1-1_{5 F}$ & $5 \mathrm{WBF}$ & 1.10 & 400 & 1:10, PBS $1 \times$ & $2 \mathrm{~mL}$ PBS $1 \times$ & 200 \\
\hline & $M 1-2_{5 F}$ & $5 \mathrm{WBF}$ & 1.10 & 400 & 1:10, PBS $1 \times$ & $2 \mathrm{~mL}$ PBS $1 \times$ & 200 \\
\hline & $\mathrm{M} 1-3_{5 \mathrm{~F}}$ & $5 \mathrm{WBF}$ & 1.10 & 400 & 1:10, PBS $1 \times$ & $2 \mathrm{~mL}$ PBS $1 \times$ & 200 \\
\hline & $M 2_{W G A}$ & sWGA & 0.23 & 400 & n.a & n.a & 200 \\
\hline & $\mathrm{M} 2-1_{5 \mathrm{~F}}$ & $5 \mathrm{WBF}$ & 0.23 & 400 & 1:10, PBS $1 \times$ & $2 \mathrm{~mL}$ PBS $1 \times$ & 200 \\
\hline & $M 2-2_{5 F}$ & $5 W B F$ & 0.23 & 400 & 1:10, PBS $1 \times$ & $2 \mathrm{~mL}$ PBS $1 \times$ & 200 \\
\hline & $\mathrm{M} 2-3_{5 \mathrm{~F}}$ & $5 \mathrm{WBF}$ & 0.23 & 400 & 1:10, PBS 1x & $2 \mathrm{~mL}$ PBS $1 \times$ & 200 \\
\hline & $M 3_{W G A}$ & sWGA & 0.022 & 400 & n.a & n.a & 200 \\
\hline & $M 3-1_{5 F}$ & $5 \mathrm{WBF}$ & 0.022 & 400 & 1:10, PBS 1x & $2 \mathrm{~mL}$ PBS $1 \times$ & 200 \\
\hline & $\mathrm{M} 3-2_{5 \mathrm{~F}}$ & $5 \mathrm{WBF}$ & 0.022 & 400 & 1:10, PBS $1 \times$ & $2 \mathrm{~mL}$ PBS $1 \times$ & 200 \\
\hline & $M 3-3_{5 F}$ & $5 \mathrm{WBF}$ & 0.022 & 400 & 1:10, PBS 1x & $2 \mathrm{~mL}$ PBS $1 \times$ & 200 \\
\hline \multirow[t]{10}{*}{ Patients } & $P 1_{5 F-50}$ & $5 \mathrm{WBF}$ & 0.04 & 50 & 1:30, RPMI 1640 & n.d & 200 \\
\hline & $P 1_{5 F-200}$ & $5 \mathrm{WBF}$ & 0.04 & 200 & 1:30, RPMI 1640 & n.d & 200 \\
\hline & $P 2_{5 F-50}$ & $5 \mathrm{WBF}$ & 0.08 & 50 & 1:30, RPMI 1640 & n.d & 200 \\
\hline & $P 2_{5 F-200}$ & $5 \mathrm{WBF}$ & 0.08 & 200 & 1:30, RPMI 1640 & n.d & 200 \\
\hline & $P 3_{5 F-50}$ & $5 \mathrm{WBF}$ & 0.25 & 50 & 1:30, RPMI 1640 & n.d & 200 \\
\hline & $P 3_{5 F-200}$ & $5 \mathrm{WBF}$ & 0.25 & 200 & 1:30, RPMI 1640 & n.d & 200 \\
\hline & $P 4_{5 F-50}$ & $5 \mathrm{WBF}$ & 0.40 & 50 & 1:30, RPMI 1640 & n.d & 200 \\
\hline & $P 4_{5 F-200}$ & $5 \mathrm{WBF}$ & 0.40 & 200 & 1:30, RPMI 1640 & n.d & 200 \\
\hline & $P 5_{5 F-50}$ & $5 \mathrm{WBF}$ & 5.50 & 50 & 1:30, RPMI 1640 & n.d & 200 \\
\hline & $P 5_{5 F-200}$ & $5 \mathrm{WBF}$ & 5.50 & 200 & 1:30, RPMI 1640 & n.d & 200 \\
\hline
\end{tabular}

\% para: parasitaemia in percentage; n.a.: not applicable; n.d.: not done

${ }^{a}$ Rinsing the filter with $2 \mathrm{~mL}$ of buffer after blood filtration is optional: as skipping the rinsing step produced satisfactory WGS results, this step was not performed for the second part of this study on parasite isolates from patients in order to simplify the protocol

${ }^{b}$ Elution buffer refers to DNA extraction from the unfiltered/filtered blood samples

Qubit $^{\circledR}$ dsDNA high sensitivity kit (Thermo Fisher Scientific) according to the manufacturer's recommendations.

\section{sWGA procedure}

The sWGA method was performed on genomic DNA from unfiltered samples according to published protocols [9]. The sWGA reaction was performed in $0.2 \mathrm{~mL}$ PCR-tubes, containing $10 \mathrm{ng}$ of template genomic DNA, $1 \times$ BSA (New England Biolabs), $1 \mathrm{mM}$ dNTPs (New England Biolabs), $2.5 \mu \mathrm{M}$ of each amplification primer (Additional file 1: Table S2), $1 \times$ Phi29 reaction buffer (New England Biolabs), 30 units of Phi29 polymerase (New England Biolabs), and molecular biology grade water to reach a final reaction volume of $50 \mu \mathrm{L}$. The reaction was carried out on a thermocycler with the following step-down program: $5 \mathrm{~min}$ at $35^{\circ} \mathrm{C}, 10 \mathrm{~min}$ at $34{ }^{\circ} \mathrm{C}$, $15 \mathrm{~min}$ at $33{ }^{\circ} \mathrm{C}, 20 \mathrm{~min}$ at $32{ }^{\circ} \mathrm{C}, 30 \mathrm{~min}$ at $31{ }^{\circ} \mathrm{C}, 16 \mathrm{~h}$ at $30{ }^{\circ} \mathrm{C}$, then heating for $15 \mathrm{~min}$ at $65{ }^{\circ} \mathrm{C}$ to inactivate the Phi29 polymerase before cooling to $4{ }^{\circ} \mathrm{C}$. Amplified products were quantified using the Qubit ${ }^{\circledR}$ dsDNA high sensitivity kit (Thermo Fisher Scientific) to determine whether there was at least $500 \mathrm{ng}$ of product for sequencing. Amplified products were cleaned using Agencourt Ampure XP beads (Beckman Coulter) as follows: 1.8 volumes of beads were added to 1 volume of amplified products, briefly mixed, and then incubated for $5 \mathrm{~min}$ at room temperature. A magnetic rack was used to capture the DNA binding beads. The DNA binding beads were then washed twice using $200 \mu \mathrm{L}$ of $80 \%$ ethanol and eluted with $60 \mu \mathrm{L}$ of EB buffer.

\section{Quantitative PCR}

The copy number of specific $P$. falciparum and human genes within the genomic DNA from patient blood samples was estimated by qPCR with Plasmodium Typage kit (Bio-Evolution, France). Briefly, as recommended by the manufacturer, $5 \mu \mathrm{L}$ of DNA extract was mixed with $15 \mu \mathrm{L}$ of Master Mix containing specific primers and probes targeting $P$. vivax and $P$. falciparum ARN18S and human $\beta$ actin genes. The reaction was carried out on a 
thermocycler (ViiA 7, Applied Biosystems) with the following program: $30 \mathrm{~s}$ at $95{ }^{\circ} \mathrm{C} ; 40$ cycles: $15 \mathrm{~s}$ at $95{ }^{\circ} \mathrm{C}$ followed by $45 \mathrm{~s}$ at $60{ }^{\circ} \mathrm{C}$; then $1 \mathrm{~s}$ at $37^{\circ} \mathrm{C}$. Positive and negative controls were included in each run.

\section{Whole-genome sequencing}

250 ng of DNA were used for mechanical DNA shearing that was performed in a total volume of $52 \mu \mathrm{L}$ with the Covaris S220 through microTube-50 AFA Fiber Screw-Cap $\left(\right.$ Covaris $\left.^{\circledR}\right)$ using a setting of $30 \%$ duty factor, $100 \mathrm{~W}$ peak incidence power, and 1000 cycles per burst for $150 \mathrm{~s}$. Note that the concentrations of genomic DNA from $5 \mathrm{WBF}$-treated blood samples were often very low or even below the Qubit $^{\circledR}$ detection threshold (Additional file 1: Table S3). Then, $52 \mu \mathrm{L}$ of undiluted genomic DNA were used for mechanical DNA shearing. Genomic DNA libraries were constructed for high throughput sequencing using the KAPA HyperPrep Library Preparation Kit (Kapa Biosystems, Woburn, MA). DNA libraries were checked for quality and quantity using Qubit ${ }^{\circledR}$ for concentration and BioAnalyser 2100 Agilent for fragment size. Libraries were sequenced at $150 \mathrm{bp}$ paired-end using an Illumina NextSeq 500 instrument at the GENOM'IC platform from Institut Cochin (Paris, France).

\section{Sequencing output analysis}

Sequence data obtained from each sample was subjected to standard Illumina QC procedures. Each sample was analysed independently by mapping sequence reads to the $P$. falciparum 3D7 reference genome v.39 using the Burrows-Wheeler Aligner (BWA) software package [14]. Samtools (http://samtools.sourceforge.net/) was used to generate coverage statistics and depth estimates from the BWA mapping output. Qualimap v2.2.1 was also used to perform an analysis based on specific features derived from the alignment, including coverage, $\mathrm{GC}$ content and mapping quality [15]. A home-made python script was developed to calculate the percentage of each $P$. falciparum gene covered at $\geq 10 \times$ depth and the per-gene mean coverage depth (https://github.com/Rcoppee/Scan gene_coverage). The script required a reference genome file in fasta format, an annotation gff file indicating the location of each exon, intron and corresponding genes, and a per-base coverage depth file generated with Bedtools genomecov function using default parameters [16]. This per-base coverage depth file was also used to plot the average read depth within $1-\mathrm{kb}$ windows across the 14 P. falciparum chromosomes using the Circos software [17]. Finally, per-gene copy number was assessed using PlasmoCNVScan, a custom read depth strategy specifically made for Plasmodium species [18].

\section{Ethical considerations}

Samples received at the French Malaria Reference Centre (Paris, France) were registered and declared for research purposes as a biobank for both the Assistance Publique des Hôpitaux de Paris and Santé Publique France. The uninfected blood sample was obtained from a patient having a negative malaria test. No institutional review board approval was required according to French legislation (article L. 1111-7 du Code de la Santé Publique, article L. 1211-2 du Code de Santé Publique, articles 39 et suivants de la loi 78-17 du 6 janvier 1978 modifiée en 2004 relative à l'informatique, aux fichiers, et aux libertés).

\section{Results}

\section{Application of $5 \mathrm{WBF}$ to mock samples}

5WBF was first applied to $400 \mu \mathrm{L}$ of mock blood samples (3D7 culture diluted in uninfected whole blood) with parasitaemias of 1.1, 0.23 and $0.022 \%$ (each in triplicate). For the unfiltered control mock sample (sample M1; 1.1\% parasitaemia), $21.2 \%$ of the reads mapped to the $P$. falciparum genome (Fig. 2a) with a mean coverage of $5.6 \times$ depth (Table 2). For the 5WBF-treated mock samples $(\mathrm{n}=9)$, an average of $89.6 \%$ (standard deviation: 11.4) of the reads mapped to the $P$. falciparum genome (Fig. 2a). The proportion of P. falciparum-mapped reads decreased with parasitaemia (Fig. 2a and Table 2). Regardless, at least $98.6 \%$ of the $P$. falciparum genome was covered at $\geq 10 \times$ depth whatever the parasitaemia (Fig. 2b). Reads also covered both the parasite's mitochondrial and apicoplast genomes, for which mean coverages were systematically higher than $1000 \times$ and $59.6 \times$ depths respectively. For comparison, one unfiltered mock sample of each parasitaemia was processed by the sWGA procedure. Lower proportions of reads mapped to the P. falciparum genome when from sWGA-treated compared to 5WBF-treated samples (Fig. 2a and Table 2). The difference was modest at $1.1 \%$ parasitaemia but it increased as parasitaemias dropped to 0.23 and $0.022 \%$. From 47.7 to $82.1 \%$ of the nuclear genome was covered at $\geq 10 \times$ depth depending on parasitaemia (Fig. 2b). Also, reads from sWGA poorly covered the parasite mitochondrial and apicoplast genomes, systematically below a mean coverage of $10 \times$ depth (Table 2). In summary almost all the bases of the different genomes of $P$. falciparum were analysable at $\geq 10 \times$ depth using $400 \mu \mathrm{L}$ of $5 \mathrm{WBF}$-treated whole blood.

Then two gene-level metrics were explored: the percentage of each $P$. falciparum gene covered at $\geq 10 \times$ depth and corresponding mean coverage. For these analyses, one 5WBF-treated sample (M2-1 $\left.1_{5 \mathrm{~F}}\right)$ and one sWGA-treated sample $\left(\mathrm{M} 2_{\text {WGA }}\right)$ that presented a similar 


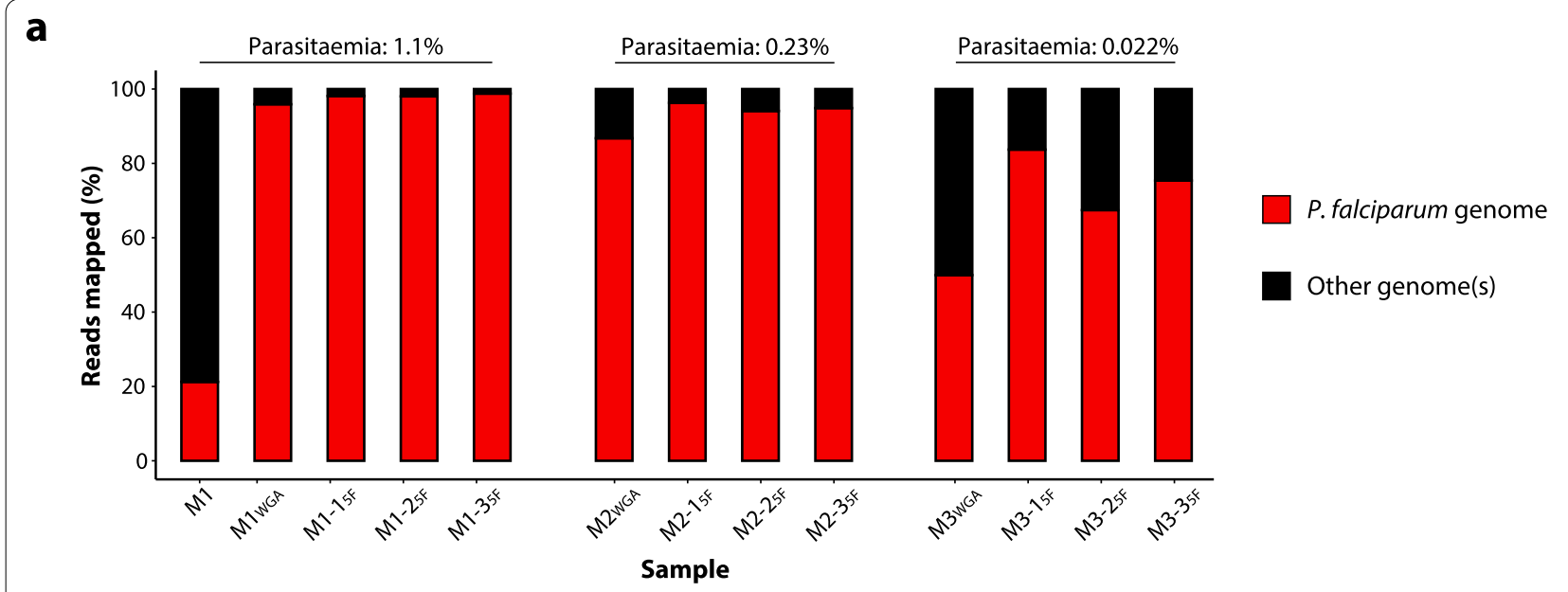

b
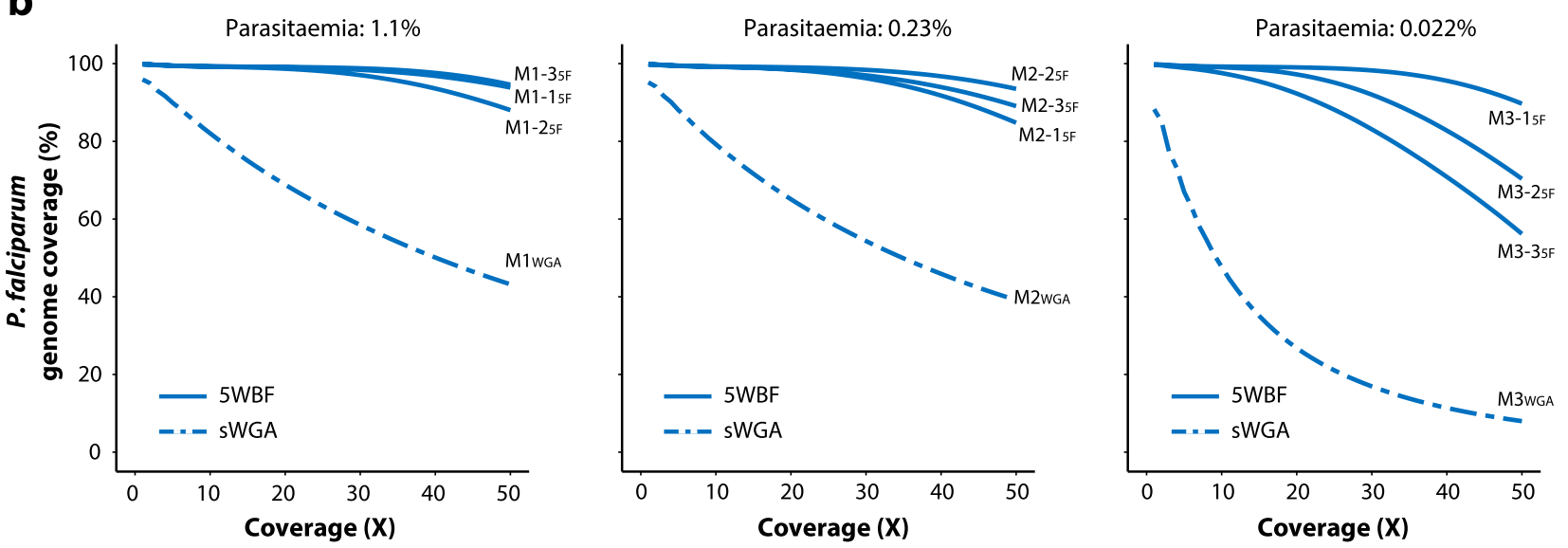

Fig. 2 Proportions of mapped reads and P. falciparum genome coverage from mock whole blood samples. a Proportion of reads mapping to the $P$. falciparum nuclear and organellar genomes. Red and black colours indicate the proportion of reads mapping and not mapping to the $P$. falciparum genomes respectively. $\mathbf{b}$ Genome fraction coverage from $1 \times$ to $50 \times$ depth. Data from sWGA- and 5WBF-treated samples are indicated in dashed and solid lines, respectively. Three independent 5WBF blood filtration replicates were made for each parasitaemia

number of reads mapping to the $P$. falciparum genome were used ( $\sim 14$ million reads; Table 2$)$.

First, for the $5 \mathrm{WBF}$-treated sample (M2-1 5 F $), 99.0 \%$ $(5404 / 5460)$ of nuclear genes and all organellar genes were fully covered at $\geq 10 \times$ depth, including important drug resistance genes such as $k 13, m d r 1, c r t, d h f r$ and dhps (Fig. 3a). The few uncovered genes were mostly rifin and var. Using sWGA, $68.5 \%(3741 / 5460)$ of $P$. falciparum genes were fully covered at $\geq 10 \times$ depth. None of the mitochondrial and apicoplast genes were covered at $\geq 10 \times$ depth, and the drug resistance gene $m d r 1$ was not fully covered at this threshold (Fig. 3b).

Second, the coverage per gene varied little with the 5 WBF sample (mean coverage: $91 \times$; median: $93 \times$; 5 th percentile: $70 \times$; 95 th percentile: $103 \times$ ) compared with the sWGA sample (mean coverage: $80 \times$; median: $51 \times$; 5th percentile: $7 \times$; 95 th percentile: $245 \times$ ) (Fig. $3 \mathrm{a}$ and b). The coverage depth was also measured at each base across the 14 chromosomes of the $P$. falciparum nuclear genome. Reads mapped homogeneously across the genome with $5 \mathrm{WBF}$, while they mapped much more heterogeneously in sWGA (Fig. 4). Consequently, 5WBF is likely compatible with analyses based on read distribution such as identifying per-gene copy number.

\section{Application of 5WBF to $P$. falciparum clinical isolates}

The $5 \mathrm{WBF}$ procedure was then tested on $P$. falciparum clinical samples with parasitaemias ranging from 0.04 to $5.5 \%$ (Table 3). For that, $50 \mu \mathrm{L}$ (i.e. one drop) and $200 \mu \mathrm{L}$ of whole blood from patients were used to match blood volumes routinely collected in a clinical context.

First, parasite and human DNA amount were assessed by qPCR, expressed in Ct (cycle threshold), before and after 5WBF (Additional file 1: Table S3). Slightly higher $\mathrm{Ct}$ values were observed after 5WBF for the parasite qPCR assay $\left(\mathrm{Ct}_{5 \mathrm{WBF}}-\mathrm{Ct}_{\text {unfiltered: }}\right.$ mean $=1.1, \min =-1$, 
Table 2 WGS statistics of P. falciparum DNA extracted from mock samples subjected to either no treatment or sWGA or 5WBF

\begin{tabular}{|c|c|c|c|c|c|c|c|}
\hline Sample name & $\%$ para & $\begin{array}{l}\text { Enrichment } \\
\text { method }\end{array}$ & Total reads & $\begin{array}{l}\text { P. falciparum- } \\
\text { mapped reads }(x)\end{array}$ & $\begin{array}{l}\text { Mean genome } \\
\text { coverage }(x)\end{array}$ & $\begin{array}{l}\text { Mean coverage of } \\
\text { mt genome }(x)\end{array}$ & $\begin{array}{l}\text { Mean coverage of } \\
\text { api genome }(x)\end{array}$ \\
\hline M1 & 1.1 & None & $14,777,245$ & $3,135,321(21.22)$ & 5.60 & 45.39 & 11.76 \\
\hline$M 1_{\text {WGA }}$ & 1.1 & sWGA & $16,002,711$ & $15,347,302(95.9)$ & 74.41 & 5.20 & 8.44 \\
\hline $\mathrm{M} 1-1_{5 \mathrm{~F}}$ & 1.1 & $5 \mathrm{WBF}$ & $19,932,109$ & $19,558,272(98.12)$ & 104.86 & 2102.17 & 216.15 \\
\hline$M 1-2_{5 F}$ & 1.1 & $5 \mathrm{WBF}$ & $16,923,729$ & $16,591,158(98.03)$ & 89.59 & 1701.08 & 183.29 \\
\hline $\mathrm{M} 1-3_{5 \mathrm{~F}}$ & 1.1 & $5 \mathrm{WBF}$ & $17,230,853$ & $17,018,367(98.77)$ & 90.04 & 1335.70 & 150.66 \\
\hline$M 2_{W G A}$ & 0.23 & sWGA & $16,266,710$ & $14,112,713$ (86.76) & 69.16 & 1.59 & 3.57 \\
\hline $\mathrm{M} 2-1_{5 \mathrm{~F}}$ & 0.23 & $5 \mathrm{WBF}$ & $14,905,078$ & $14,350,236(96.28)$ & 79.71 & 1468.76 & 120.40 \\
\hline $\mathrm{M} 2-2_{5 \mathrm{~F}}$ & 0.23 & $5 \mathrm{WBF}$ & $19,310,196$ & $18,169,487(94.09)$ & 99.82 & 1782.77 & 161.75 \\
\hline $\mathrm{M} 2-3_{5 \mathrm{~F}}$ & 0.23 & $5 \mathrm{WBF}$ & $17,672,315$ & $16,766,350(94.87)$ & 91.15 & 1933.32 & 129.47 \\
\hline$M 3_{W G A}$ & 0.022 & sWGA & $9,840,798$ & $4,915,197(49.95)$ & 18.63 & 0.31 & 2.34 \\
\hline$M 3-1_{5 F}$ & 0.022 & $5 \mathrm{WBF}$ & $17,283,136$ & $14,467,900(83.71)$ & 76.72 & 1209.77 & 115.57 \\
\hline $\mathrm{M} 3-2_{5 \mathrm{~F}}$ & 0.022 & $5 \mathrm{WBF}$ & $17,759,091$ & $11,975,821(67.43)$ & 62.32 & 1528.46 & 98.56 \\
\hline $\mathrm{M} 3-3_{5 \mathrm{~F}}$ & 0.022 & $5 \mathrm{WBF}$ & $13,052,530$ & $9,839,100(75.38)$ & 52.17 & 1026.41 & 59.63 \\
\hline
\end{tabular}

Reads were mapped to the $P$. falciparum $3 \mathrm{D} 7$ reference genome v.39

$\%$ para: parasitaemia in percentage; $m t$ mitochondrial; api: apicoplast

$\max =3 ; \mathrm{n}=5$ samples). In contrast, a dramatic increase in $\mathrm{Ct}$ values was observed after $5 \mathrm{WBF}$ for the human $\mathrm{qPCR}$ assay $\left(\mathrm{Ct}_{5 \mathrm{WBF}}-\mathrm{Ct}_{\text {unfiltered: }}\right.$ mean $=14, \min =10$, $\max =16 ; \mathrm{n}=5$ samples). Accordingly, the amount of total genomic DNA quantified by Qubit was dramatically lower in the 5WBF-treated samples compared to their unfiltered counterparts (Additional file 1: Table S3).

With WGS data, an average of $81.4 \%$ (standard deviation: 13.0) and 94.0\% (standard deviation: 4.5) of the reads mapped to the $P$. falciparum genome when $50 \mu \mathrm{L}$ and $200 \mu \mathrm{L}$ of whole blood were filtered, respectively (Fig. $5 \mathrm{a}$ and Table 3). The mean genome coverage, including organellar genomes, was systematically higher for 200 $\mu \mathrm{L}$ than $50 \mu \mathrm{L}$ of whole blood (Table 3 ). However, at the $10 \times$ depth threshold, the $P$. falciparum genome coverage was similar whether using $50 \mu \mathrm{L}$ or $200 \mu \mathrm{L}$ of whole blood (average: 97\%; standard deviation: 1.2; Fig. 5b).

Then the same two gene-level metrics were explored as previously done for mock samples. For these analyses, the $50 \mu \mathrm{L}$ and $200 \mu \mathrm{L}$ samples from the patient P1 were selected (parasitaemia of $0.04 \% ; \mathrm{P} 1_{5 \mathrm{~F}-50}$ and $\mathrm{P} 1_{5 \mathrm{~F}-200}$; Table 3) because they presented a roughly similar number of reads mapping to the $P$. falciparum genome. $89.7 \%$ (4900/5460) and $91.8 \%(5015 / 5460)$ of $P$. falciparum genes were fully covered at $\geq 10 \times$ depth with $\mathrm{P} 1_{5 \mathrm{~F}-50}$ and $\mathrm{P} 1_{5 \mathrm{~F}-200}$, respectively, including the major drug resistance genes and all organellar genes (Fig. 6). The coverage $(x)$ per gene metrics (mean, median, and 5th and 95th percentiles) were roughly twice larger for $\mathrm{P} 1_{5 \mathrm{~F}-200}$ compared to $\mathrm{P} 1_{5 \mathrm{~F}-50}$, except for apicoplast genes (Fig. 6). The pergene copy number was then compared for $\mathrm{P} 1_{5 \mathrm{~F}-50}$ and $\mathrm{P} 1_{5 \mathrm{~F}-200}$. Beforehand, all the variant surface antigens gene families (var, stevor, rifin, phist and Plasmodium exported protein-encoding genes) were removed to avoid any bias in the analysis (4816 remaining genes). Similar profiles were obtained for $\mathrm{P} 1_{5 \mathrm{~F}-50}$ and $\mathrm{P} 1_{5 \mathrm{~F}-200}$ and no gene amplification was detected for P1 isolate (Spearman's rank correlation: $p<0.001, \mathrm{r}=0.72$; Fig. $7 \mathrm{a}$ ). Among the other tested samples, P5 5 F-50 and $\mathrm{P} 5_{5 \mathrm{~F}-200}$ each harbored three copies of the GTP cyclohydrolase 1 gene (gch1; PF3D7_1224000) and of the four genes neighbouring gch1 (PF3D7_1223700, PF3D7_1223800, PF3D7_1223900 and PF3D7_1224100; Fig. 7b). The total amplicon size was $10.5 \mathrm{~kb}$ and resembled to the one detected in Thai isolates [19]. Altogether, $50 \mu \mathrm{L}$ of whole blood at $0.04 \%$ parasitaemia treated by $5 \mathrm{WBF}$ permitted to explore pergene copy number in a clinical context.

\section{Discussion}

The ability to produce high-quality sequencing data from P. falciparum clinical samples has valuable implications for public health. The sWGA method has massively facilitated the generation of WGS from clinical whole blood samples stored on dried blood spot (DBS). However, sWGA-based methods present several drawbacks. Current primers used to selectively amplify the $P$. falciparum genome lead to the nearly complete loss of the mitochondrial and apicoplast genomes [9]. Furthermore, a large proportion of reads often do not map to the P. falciparum genome, suggesting that some contaminant human DNA remains after the sWGA step [12] and which increases the sequencing cost. Finally, reads mapping to the reference genome are not homogeneously distributed across the genome, precluding any investigation based on read 


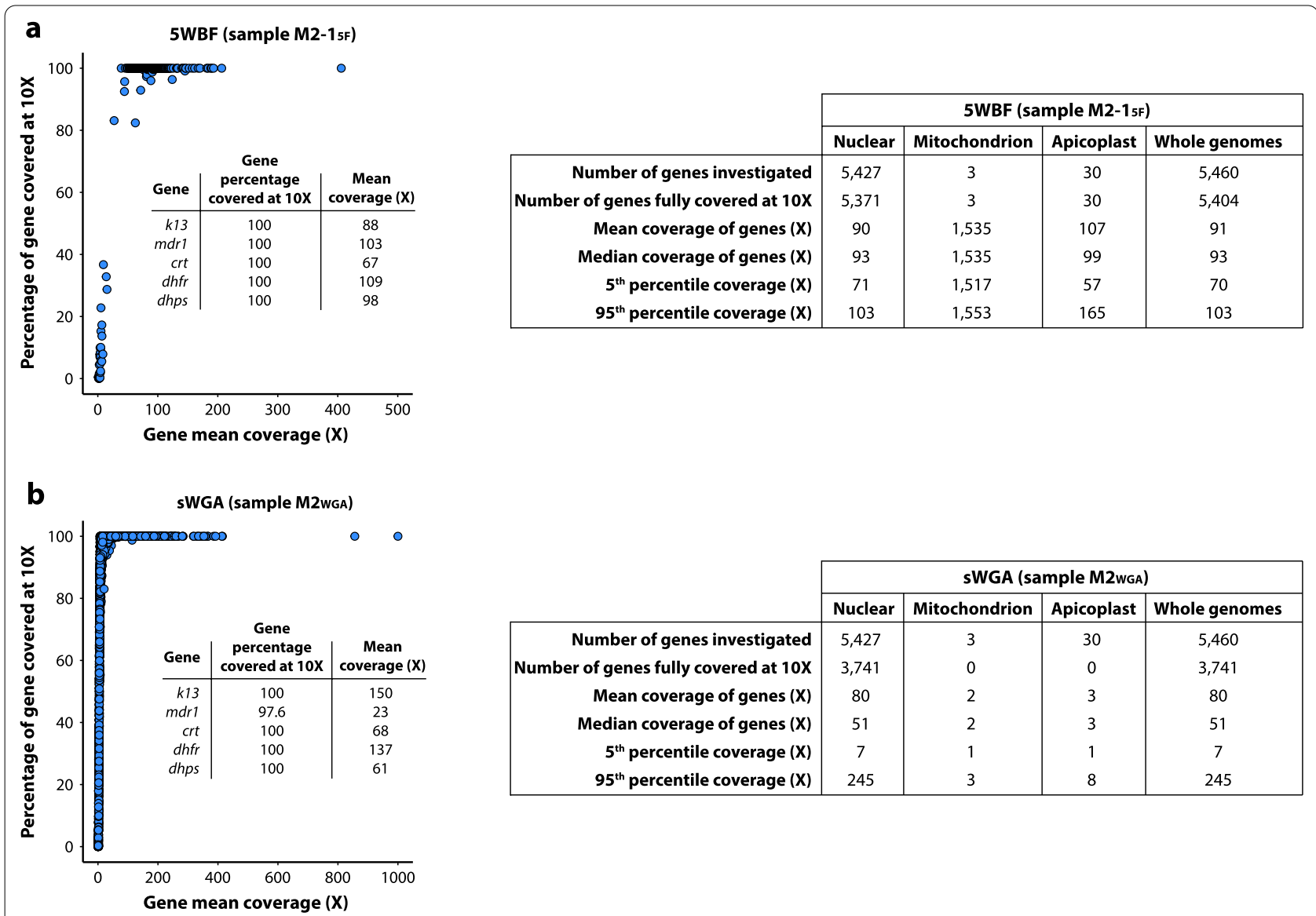

Fig. 3 Comparison of gene coverage depth between $M 2_{W G A}$ and $M 2-1_{5 F}$ mock samples. a Coverage depth and gene percentage covered at $\geq 10 \times$ depth of all genes for $\mathrm{M} 2-1_{5 \mathrm{~F}}$. Each blue point corresponds to a gene. Mitochondrial genes were discarded for ease of representation. The insert table indicates the mean coverage and the percentage of genes covered at $\geq 10 \times$ depth for five drug resistance genes. Descriptive statistics on the right table included the total number of $P$. falciparum (3D7) genes, the number of genes fully covered at $\geq 10 \times$ depth, the mean and median coverage of all genes, and the 5th and 95th percentiles of coverage depth. Genes were partitioned as of either nuclear, mitochondrial, or apicoplast origins. $\mathbf{b}$ Coverage depth of all genes for $\mathrm{M}_{2}$ WGA . Description of the plot and the tables are the same as in $\mathbf{a}$

distribution such as the measure of per-gene copy number [18].

Here, the usefulness of $5 \mathrm{WBF}$ as a new leucodepletion protocol based on commercial $5 \mu \mathrm{m}$ filters was shown. Other filtration approaches were already successfully developed but also have their own drawbacks-whether in terms of costs, blood volumes, or standardization [7, 8 ]. In this work, $5 \mathrm{WBF}$ was used for WGS purposes, but this strategy may likely be useful for other sequencing applications, such as RNAseq, which often suffers from contaminant human DNA when applied to P. falciparum isolates and thus requiring additional costs.

Sequencing data obtained with whole blood samples treated by $5 \mathrm{WBF}$ revealed that all the three $P$. falciparum genomes (nuclear, mitochondrial and apicoplast) were covered with high coverage depth. Almost all of the $P$. falciparum genes were fully covered at $\geq 10 \times$ depth, except the highly variable var and rifin gene families. Capturing the organellar genomes is especially important since they carry drug resistance genes, such as cytb or rps4 [20-22], or can inform on the geographic origin and evolution of the parasites [23]. Finally, the homogeneous distribution of reads across the genome makes it possible to detect gene copy number variations, some of which are genotypic markers of anti-malarial drug resistance [24-26].

The $5 \mathrm{WBF}$ procedure was extensively tested here using the $5 \mu \mathrm{m}$ Minisart $\mathrm{NML}^{\circledR}$ syringe filter from the manufacturer Sartorius. Other commercially available $5 \mu \mathrm{m}$ might also be suitable and would need validation experiments. Financially, the cost of the $5 \mu \mathrm{m}$ Minisart NML ${ }^{\circledR}$ syringe filter varies from 1.0 to $1.7 €$ per unit depending on suppliers. This seems about 10 times cheaper than the Plasmodipur filter (Europroxima, Arnhem, The Netherlands, Cat. 8011Filter25U) [6, 8]. Similarly, sWGA-based methods are more expensive than 5WBF since Phi29 


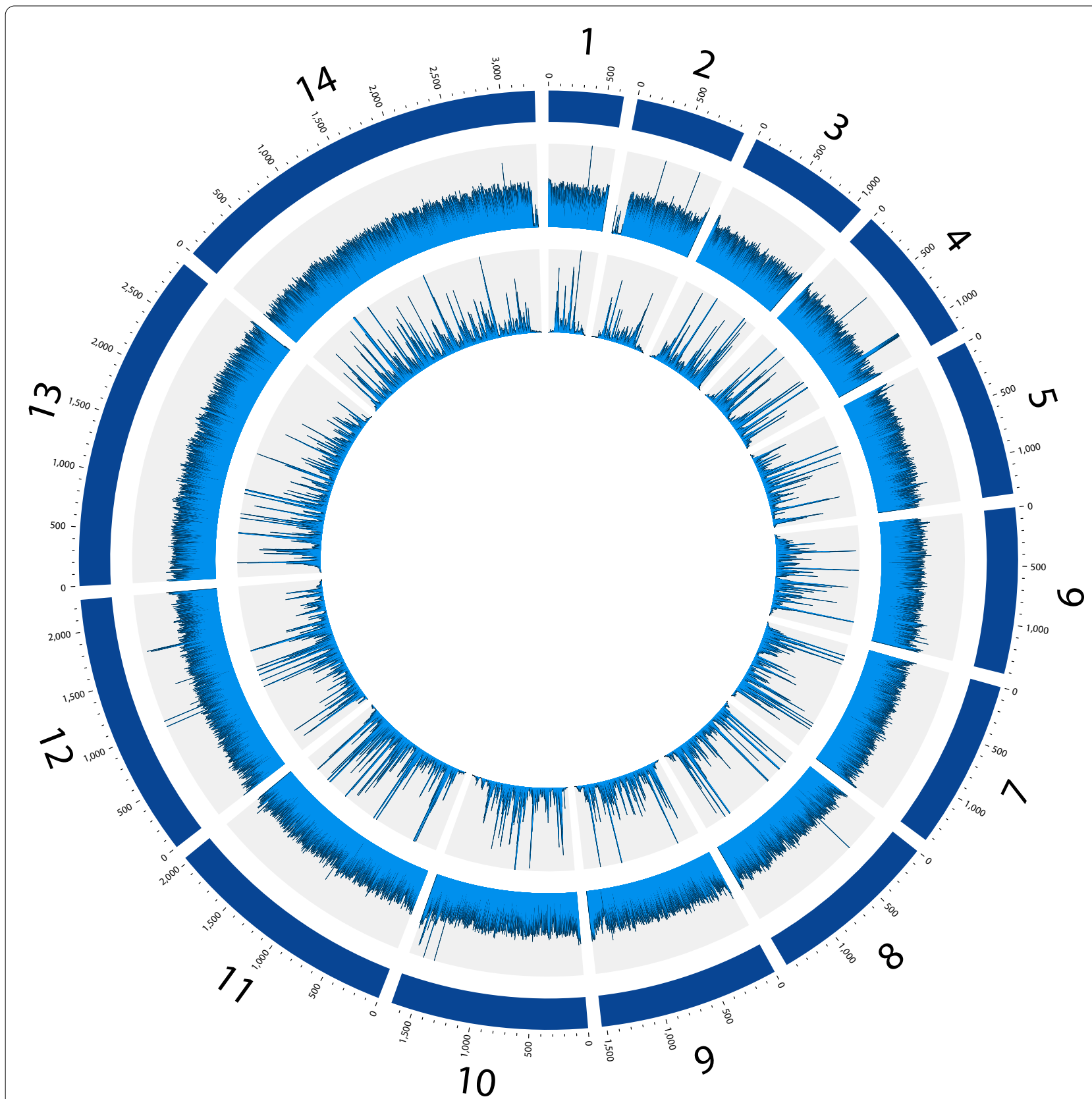

Fig. 4 Distribution of the reads along the 14 chromosomes of the $P$. falciparum nuclear genome for $\mathrm{M} 2-1_{5 \mathrm{~F}}$ and $\mathrm{M} 2_{\mathrm{WGA}}$ mock samples. The three rings represent, from outermost to innermost, the 14 chromosomes of the $P$. falciparum nuclear genome (illustrated to scale in kb), and the average read depth within 1-kb windows for $M 2-1_{5 F}$ and for $M 2_{W G A}$ respectively. For ease of representation, the maximum depth for $M 2-1_{5 F}$ and $M 2_{W G A}$ was fixed at $200 x$ and $500 x$, respectively

DNA polymerase, primer sets and subsequent purification with Agencourt Ampure XP beads increase the cost to approximately $6-8 €$ per sample [9-11]. The leucodepletion-based method through CF11 cellulose column likely has a roughly similar implementation cost than 5WBF [7]. However, these are homemade columns and thus requires an extended preparation time, and likely lack the standardized and certified quality of commercially available filters. Altogether, the $5 \mathrm{WBF}$ procedure provides remarkable add-ons: simplicity and speed of the filtration procedure, standardized and ready-to-use sterile filters, low cost per sample, and high quality of WGS data. Also, 5WBF-treated blood samples could probably be easily stored after centrifugation as DBS on filter 
Table 3 WWBF-based WGS statistics from five P. falciparum clinical isolates

\begin{tabular}{|c|c|c|c|c|c|c|c|c|}
\hline Patient & $\%$ para & Sample name & $\begin{array}{l}\text { Volume of } \\
\text { blood filtered } \\
(\mu \mathrm{L})\end{array}$ & Total reads & $\begin{array}{l}\text { P. falciparum- } \\
\text { mapped reads } \\
(\%)\end{array}$ & $\begin{array}{l}\text { Mean genome } \\
\text { coverage }(x)\end{array}$ & $\begin{array}{l}\text { Mean coverage } \\
\text { of } \mathrm{mt} \text { genome } \\
(x)\end{array}$ & $\begin{array}{l}\text { Mean coverage of } \\
\text { api genome }(x)\end{array}$ \\
\hline \multirow[t]{2}{*}{ P1 } & 0.04 & $P 1_{5 F-50}$ & 50 & $12,179,133$ & $9,487,373$ (77.90) & 49.97 & 664.63 & 38.04 \\
\hline & & $P 1_{5 F-200}$ & 200 & $11,913,069$ & $11,363,989(95.39)$ & 60.43 & 910.04 & 45.12 \\
\hline \multirow[t]{2}{*}{ P2 } & 0.08 & $P 2_{5 F-50}$ & 50 & $11,305,296$ & $7,949,064(70.31)$ & 40.96 & 534.58 & 53.71 \\
\hline & & $P 2_{5 F-200}$ & 200 & $10,668,907$ & $9,273,820(86.92)$ & 49.09 & 807.60 & 61.40 \\
\hline \multirow[t]{2}{*}{ P3 } & 0.25 & $P 3_{5 F-50}$ & 50 & $11,727,334$ & $10,693,769(91.19)$ & 59.79 & 490.97 & 48.93 \\
\hline & & $P 3_{5 F-200}$ & 200 & $15,203,526$ & $14,512,154(95.45)$ & 77.68 & 628.79 & 80.60 \\
\hline \multirow[t]{2}{*}{ P4 } & 0.40 & $P 4_{5 F-50}$ & 50 & $12,500,393$ & $8,627,931(69.02)$ & 44.39 & 449.46 & 79.74 \\
\hline & & $P 4_{5 F-200}$ & 200 & $13,886,282$ & $12,952,939(93.28)$ & 68.77 & 779.27 & 106.35 \\
\hline \multirow[t]{2}{*}{ P5 } & 5.50 & $P 5_{5 F-50}$ & 50 & $22,830,831$ & $22,459,337(98.37)$ & 117.53 & 1219.30 & 240.98 \\
\hline & & $P 5_{5 F-200}$ & 200 & $28,206,251$ & $27,924,816(99.00)$ & 147.98 & 1483.73 & 357.97 \\
\hline
\end{tabular}

\% para: parasitaemia in percentage; mt: mitochondrial; api: apicoplast

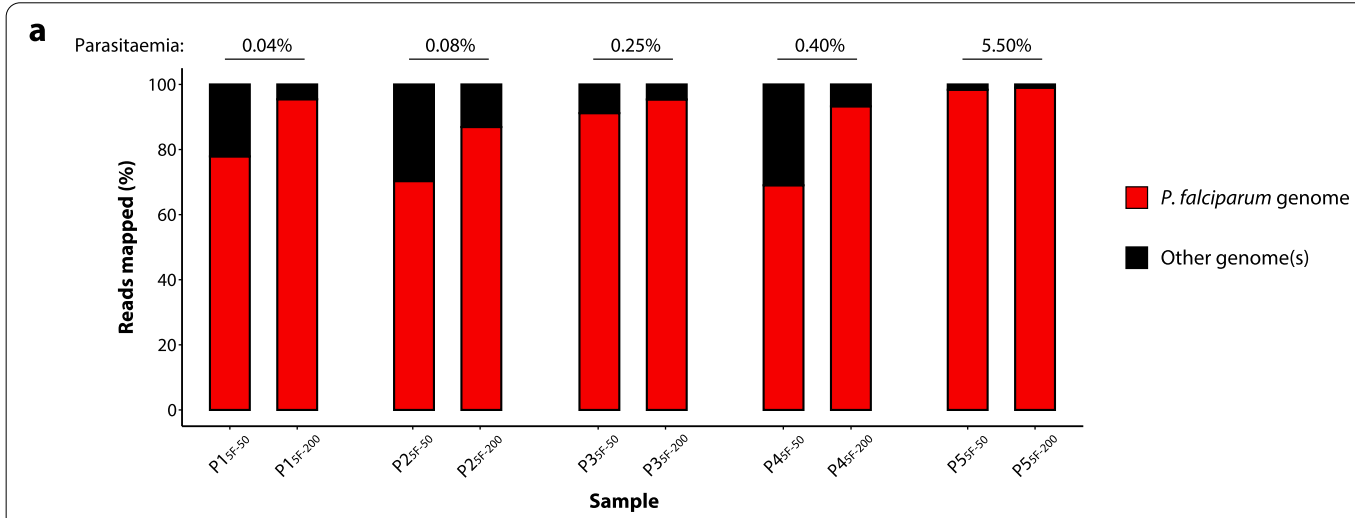

b
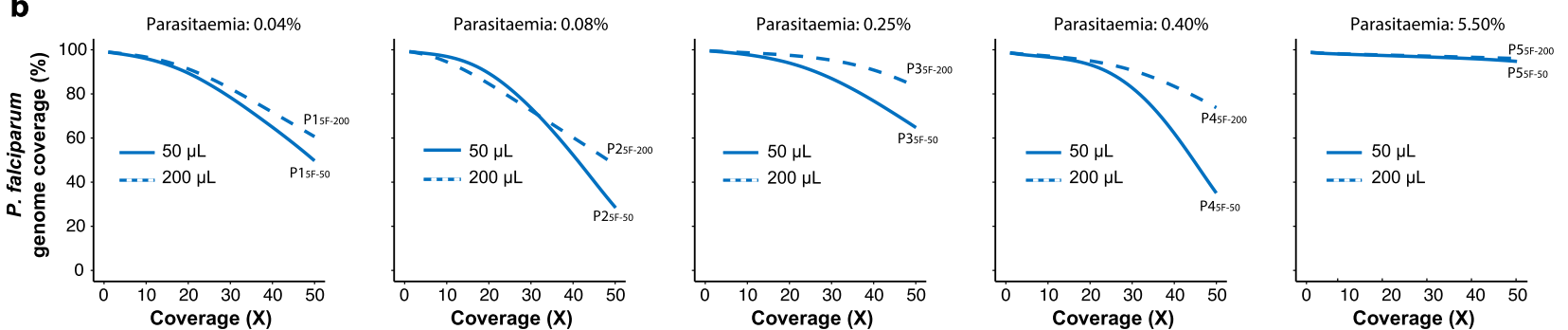

Fig. 5 Proportions of mapped reads and P. falciparum genome coverage from clinical samples. a Proportion of reads mapping to the P. falciparum nuclear and organellar genomes. Red and black colours respectively indicate the proportion of reads mapping and not mapping to the $P$. falciparum genomes. b Genome fraction coverage from $1 \times$ to $50 \times$ depth. Data from $50 \mu \mathrm{L}$ and $200 \mu \mathrm{L}$ of filtered whole blood are indicated in solid and dashed lines, respectively

papers, in the exact same way as was previously done with Plasmodipur filtration [8]. This possibility remains to be tested.

The $5 \mathrm{WBF}$ procedure has some limitations. First, as for any filtration procedure, it introduces practical constraints related to the centrifugation of the resulting filtrate to pellet RBCs. If no power is available on preparation site, the $5 \mathrm{WBF}$-filtered RBCs could then be left to precipitate for approximately $3 \mathrm{~h}$ as previously done [8]. Second, it was successful mainly for blood samples infected with $P$. falciparum parasites at the ring-stage, which correspond to the vast majority of $P$. falciparum clinical isolates. In $5 \mathrm{WBF}$ experiments with asynchronous in vitro 3D7 parasite culture, erythrocytes infected with more mature $P$. falciparum stages like mature trophozoites and schizonts were not consistently 


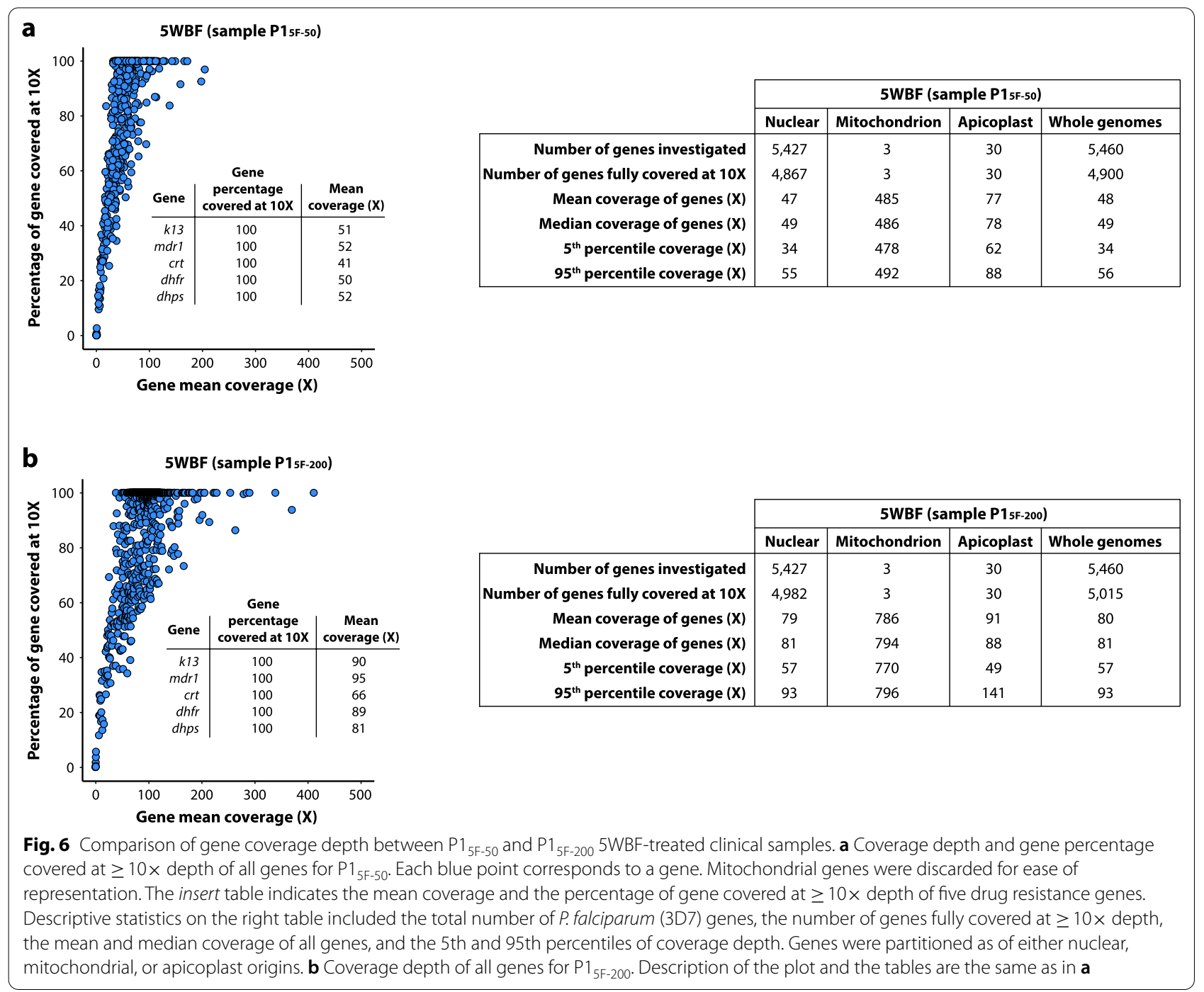

recovered in the $5 \mathrm{WBF}$ filtrate. Of note, the filtrated ringstage 3D7 parasites were viable and could mature and replicate in culture. Few Plasmodium ovale, Plasmodium malariae and Plasmodium vivax clinical samples were also tested and a large parasite DNA loss was obtained in some samples after $5 \mathrm{WBF}$. Therefore, at this stage, it is not recommended to use the $5 \mathrm{WBF}$ method to recover erythrocytes infected by non-falciparum species, being co-infections or not, nor by more mature $P$. falciparum stages like mature trophozoites and schizonts.

\section{Conclusion}

In summary, $5 \mathrm{WBF}$ is a simple and cheap filtration procedure that depletes leukocytes from human blood. $5 \mathrm{WBF}$ treatment of minute amounts of clinical blood samples permits extensive genome-wide analysis of $P$. falciparum, including the coverage of organellar genomes and the detection of gene copy number variations.
Abbreviations

5WBF: 5 MM Whole Blood Filtration; Ct: Cycle threshold; DBS: Dried blood spots; RBCs: Red blood cells; sWGA: Selective whole-genome amplification; WGS: Whole-genome sequencing.

\section{Supplementary Information}

The online version contains supplementary material available at https://doi. org/10.1186/s12936-022-04073-1.

Additional file 1: Figure S1. Alternative 5WBF protocol. Table S1. Clinical information of the patients included in the study. Table S2. sWGA primers for $P$. falciparum. Table S3. Content in P. falciparum and total DNA before and after 5WBF measured by qPCR and Qubit.

Acknowledgements

Not applicable.

Authors' contributions

RC, FA, SH, and JC conceived and coordinated the study. AM, VS, CK, and LP performed the filtrations. RC performed SWGA. SH and VS participated in sample collection. LA and FL performed next-generation sequencing. RC 

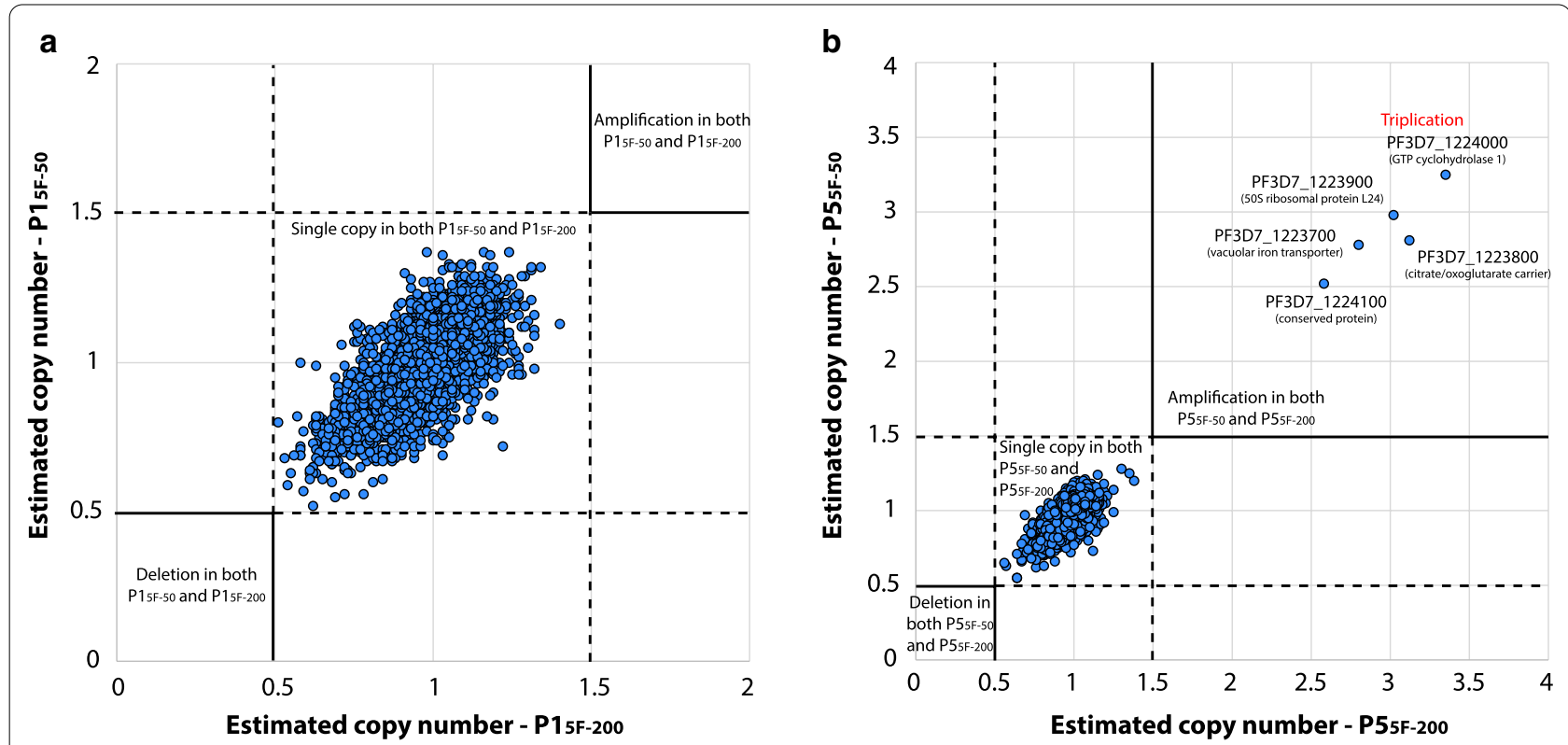

Fig. 7 Estimation of per-gene copy number for clinical samples using WGS data and the PlasmoCNVScan program. Per-gene copy number was shown for the $\mathrm{P} 1_{5 F-50}$ and $\mathrm{P} 1_{5 F-200}$ samples (a), and for the $\mathrm{P} 5_{5 F-50}$ and $\mathrm{P} 5_{5 F-200}$ samples (b). Each point corresponds to a gene. A value $<0.5$ suggests a gene deletion, while a value $>1.5$ suggests a gene amplification. Values between 0.5 and 1.5 suggests a single copy gene. A positive correlation was observed for gene copy numbers estimated using $50 \mu \mathrm{L}$ and $200 \mu \mathrm{L}$ of blood for a same isolate (Spearman's rank correlation: $p<0.001$ and $r=0.72$ for the $\mathrm{P} 1_{5 F-50}$ and $\mathrm{P} 1_{5 F-200}$ paired samples; $p<0.001$ and $r=0.84$ for the $P 5_{5 F-50}$ and $P 5_{5 F-200}$ paired samples)

performed data analyses and script production. RC drafted the manuscript $\mathrm{RC}, \mathrm{AM}, \mathrm{VS}, \mathrm{CK}, \mathrm{FA}, \mathrm{SH}$ and JC participated in the editing and final preparation of the manuscript. All authors read and approved the final manuscript.

\section{Funding}

This work was partly supported by Santé Publique France (to S.H.), the Agence Nationale de la Recherche (ANR-17-CE15-0013-03 to J.C.).

\section{Availability of data and materials}

The script used to calculate the percentage of each P. falciparum gene covered at $\geq 10 \times$ depth and the per-gene mean coverage depth was deposited on github: https://github.com/Rcoppee/Scan_gene_coverage. The datasets analysed in the study are available from the corresponding authors on request.

\section{Declarations}

\section{Ethics approval and consent to participate}

No institutional review board approval was required according to French legislation (article L. 1111-7 du Code de la Santé Publique, article L. 1211-2 du Code de Santé Publique, articles 39 et suivants de la loi 78-17 du 6 janvier 1978 modifiée en 2004 relative à l'informatique, aux fichiers, et aux libertés). Samples received at the French Malaria Reference Centre, (Paris, France) were registered and declared for research purposes as a biobank for both the Assistance Publique des Hôpitaux de Paris and Santé Publique France.

\section{Consent for publication}

There are no case presentations that require disclosure of respondent's confidential data/information in this study.

\section{Competing interests}

The authors declare that they have no competing interests.

\section{Author details}

${ }^{1}$ Université de Paris, IRD, MERIT, 75006 Paris, France. ${ }^{2}$ Centre National de Référence du Paludisme, AP-HP, Hôpital Bichat - Claude-Bernard, 75018 Paris,
France. ${ }^{3}$ Cumming School of Medicine, Pathology and Laboratory Medicine, The University of Calgary, Calgary, AB, Canada. ${ }^{4}$ Cochin Institute, INSERM U1016, UMR CNRS 8104, Genomic Platform, 75014 Paris, France. ${ }^{5}$ Université de Paris, INSERM 1016, Service de Parasitologie-Mycologie Hôpital Cochin, 75014 Paris, France. ${ }^{6}$ Present Address: Université de Paris, Infection Modelisation Antimicrobial Evolution (IAME), Inserm UMR1 137, 75018 Paris, France.

Received: 27 September 2021 Accepted: 31 January 2022

Published online: 16 February 2022

\section{References}

1. Ng PC, Kirkness EF. Whole genome sequencing. Methods Mol Biol. 2010;628:215-26.

2. Manske M, Miotto O, Campino S, Auburn S, Almagro-Garcia J, Maslen $\mathrm{G}$, et al. Analysis of Plasmodium falciparum diversity in natural infections by deep sequencing. Nature. 2012;487:375-9.

3. Amambua-Ngwa A, Amenga-Etego L, Kamau E, Amato R, Ghansah A, Golassa $L$, et al. Major subpopulations of Plasmodium falciparum in sub-Saharan Africa. Science. 2019;365:813-6.

4. Ariey F, Witkowski B, Amaratunga C, Beghain J, Langlois A-C, Khim N, et al. A molecular marker of artemisinin-resistant Plasmodium falciparum malaria. Nature. 2014;505:50-5.

5. MalariaGEN Plasmodium falciparum Community Project. Genomic epidemiology of artemisinin resistant malaria. Elife. 2016;5:e08714.

6. Auburn S, Campino S, Clark TG, Djimde AA, Zongo I, Pinches R, et al. An effective method to purify Plasmodium falciparum DNA directly from clinical blood samples for whole genome high-throughput sequencing. PLoS ONE. 2011;6:e22213.

7. Venkatesan $M$, Amaratunga C, Campino S, Auburn S, Koch O, Lim P. et al. Using CF11 cellulose columns to inexpensively and effectively remove human DNA from Plasmodium falciparum-infected whole blood samples. Malar J. 2012;11:41. 
8. Nag S, Kofoed P-E, Ursing J, Lemvigh CK, Allesøe RL, Rodrigues A, et al. Direct whole-genome sequencing of Plasmodium falciparum specimens from dried erythrocyte spots. Malar J. 2018;17:91.

9. Oyola SO, Ariani CV, Hamilton WL, Kekre M, Amenga-Etego LN, Ghansah $A$, et al. Whole genome sequencing of Plasmodium falciparum from dried blood spots using selective whole genome amplification. Malar J. 2016;15:597.

10. Shah Z, Adams M, Moser KA, Shrestha B, Stucke EM, Laufer MK, et al. Optimization of parasite DNA enrichment approaches to generate whole genome sequencing data for Plasmodium falciparum from low parasitaemia samples. Malar J. 2020;19:135.

11. Teyssier NB, Chen A, Duarte EM, Sit R, Greenhouse B, Tessema SK. Optimization of whole-genome sequencing of Plasmodium falciparum from low-density dried blood spot samples. Malar J. 2021;20:116.

12. Guggisberg AM, Sundararaman SA, Lanaspa M, Moraleda C, González $R$, Mayor A, et al. Whole-genome sequencing to evaluate the resistance landscape following antimalarial treatment failure with fosmidomycinclindamycin. J Infect Dis. 2016;214:1085-91.

13. Namvar A, Blanch AJ, Dixon MW, Carmo OMS, Liu B, Tiash S, et al. Surface area-to-volume ratio, not cellular viscoelasticity, is the major determinant of red blood cell traversal through small channels. Cell Microbiol. 2021;23:e13270.

14. Li H, Durbin R. Fast and accurate short read alignment with BurrowsWheeler transform. Bioinformatics. 2009;25:1754-60.

15. Okonechnikov K, Conesa A, García-Alcalde F. Qualimap 2: advanced multi-sample quality control for high-throughput sequencing data. Bioinformatics. 2016;32:292-4.

16. Quinlan AR, Hall IM. BEDTools: a flexible suite of utilities for comparing genomic features. Bioinformatics. 2010;26:841-2.

17. Krzywinski M, Schein J, Birol I, Connors J, Gascoyne R, Horsman D, et al. Circos: an information aesthetic for comparative genomics. Genome Res. 2009;19:1639-45.

18. Beghain J, Langlois A-C, Legrand E, Grange L, Khim N, Witkowski B, et al. Plasmodium copy number variation scan: gene copy numbers evaluation in haploid genomes. Malar J. 2016;15:206.

19. Nair S, Miller B, Barends M, Jaidee A, Patel J, Mayxay M, et al. Adaptive copy number evolution in malaria parasites. PLoS Genet. 2008;4:e1000243.

20. Korsinczky M, Chen N, Kotecka B, Saul A, Rieckmann K, Cheng Q. Mutations in Plasmodium falciparum cytochrome $b$ that are associated with atovaquone resistance are located at a putative drug-binding site. Antimicrob Agents Chemother. 2000;44:2100-8.

21. Cottrell G, Musset L, Hubert V, Le Bras J, Clain J, Atovaquone-Proguanil Treatment Failure Study Group. Emergence of resistance to atovaquoneproguanil in malaria parasites: insights from computational modeling and clinical case reports. Antimicrob Agents Chemother. 2014;58:4504-14.

22. Blasco B, Leroy D, Fidock DA. Antimalarial drug resistance: linking Plasmodium falciparum parasite biology to the clinic. Nat Med. 2017;23:917-28.

23. Preston MD, Campino S, Assefa SA, Echeverry DF, Ocholla H, AmambuaNgwa A, et al. A barcode of organellar genome polymorphisms identifies the geographic origin of Plasmodium falciparum strains. Nat Commun. 2014;5:4052.

24. Price RN, Uhlemann A-C, Brockman A, McGready R, Ashley E, Phaipun $L$, et al. Mefloquine resistance in Plasmodium falciparum and increased pfmdr 1 gene copy number. Lancet. 2004;364:438-47.

25. Sidhu ABS, Uhlemann A-C, Valderramos SG, Valderramos J-C, Krishna S, Fidock DA. Decreasing pfmdr1 copy number in Plasmodium falciparum malaria heightens susceptibility to mefloquine, lumefantrine, halofantrine, quinine, and artemisinin. J Infect Dis. 2006;194:528-35.

26. Witkowski B, Duru V, Khim N, Ross LS, Saintpierre B, Beghain J, et al. A surrogate marker of piperaquine-resistant Plasmodium falciparum malaria: a phenotype-genotype association study. Lancet Infect Dis. 2017;17:174-83.

\section{Publisher's Note}

Springer Nature remains neutral with regard to jurisdictional claims in published maps and institutional affiliations.

Ready to submit your research? Choose BMC and benefit from:

- fast, convenient online submission

- thorough peer review by experienced researchers in your field

- rapid publication on acceptance

- support for research data, including large and complex data types

- gold Open Access which fosters wider collaboration and increased citations

- maximum visibility for your research: over 100M website views per year

At BMC, research is always in progress.

Learn more biomedcentral.com/submissions 